\title{
Application of Powder Metallurgy in Production of Biomaterials
}

Pavel Novák, Kateřina Nová, Adriana Bernatiková, Andrea Školáková, Pavel Salvetr

University of Chemistry and Technology, Prague, Department of Metals and Corrosion Engineering, Technická 5, 166 28 Prague 6, Czech Republic, E-mail: panovak@vscht.cz

\begin{abstract}
Metallic biomaterials are currently produced mainly by conventional metallurgical processes, i.e. the melting and casting used e.g. in production of cobalt alloy implants, or forming processes as cold or hot working (rolling or forging of stainless steel for surgical applications). Such processes including melting are used also in production of "smart" biomaterials - NiTi shape memory alloys. The mechanical properties are strongly dependent on the grain size. Therefore, the techniques to obtain finer structure are very desirable to enhance the mechanical properties of the biomaterials and thus to increase lifetime of the implant. This paper is devoted to the description of the possibilites of powder metallurgy not only for the structure refinement, but also for the ptoduction of clean biomedical alloys as well as the porous bioamterials. The use of powder metallurgy is described for Co-Cr-Mo surgical alloy, Ni-Ti shape memory alloy and Ti-based porous biomaterial. In addtion to known methods, new powder metallurgy processes and materials developed by the authors are presented.
\end{abstract}

Keywords: powder metallurgy, biomaterials, microstructure, properties

\section{Acknowledgement}

This research was financially supported by the Czech Science Foundation, project No. 14-03044S, and by the by the project TE01020390 financed by Technology Agency of the Czech Republic.

\section{References}

[1] MICHALCOVÁ, A., VOJTĚCH, D. (2012). Structure of rapidly solidified aluminium alloys. In: Manufacturing Technology, Vol. 12, No. 13, pp. 166-169. UJEP. Czech Republic.

[2] NOVÁK P., ŠKOLÁKOVÁ A., VOJTĚCH V., KNAISLOVÁ A., POKORNÝ P., MORAVEC H., KOPEČEK J., KARLÍK M., KUBATÍK T.F. (2014). Application of Microscopy and X-ray Diffraction in Optimization of the Production of NiTi Alloy by Powder Metallurgy. In: Manufacturing Technology, Vol. 14, pp. 387-392.

[3] NOVÁK, P., VOdĚROVÁ, M., HENDRYCH, R., KUBATÍK, T., MiCHALCOVÁ, A., VOJTĚCH, D. (2013). Preparation of aluminium-based quasicrystals. In: Manufacturing Technology, Vol. 13, No. 3, pp. 390-394. UJEP. Czech Republic.

[4] NOVÁK, P. (2015). Patent CZ 305703.

[5] NOVÁK, P., MORAVEC, H., SALVETR, P., PRŮŠA, F., DRAHOKOUPIL, J., KOPEČEK, J., KARLÍK, M., KUBATÍK, T.F. (2015). Preparation of nitinol by non-conventional powder metallurgy techniques. In: Materials Science and Technology, Vol. 31, No. 15, pp. 1886-1893. Taylor and Francis.

[6] VOJTĚCH, D., KUBÁSEK, J., NOVÁK, P. (2013). Corrosion properties of the superelastic shape memory Ni-Ti alloy for medical implants. In: Manufacturing Technology, Vol. 13, No. 3, pp. 409-414. UJEP. Czech Republic.

[7] FOROOZMEHR, A., KERMANPUR, A., ASHRAFIZADEH, F., KABIRI, Y. (2011) Investigating microstructural evolution during homogenization of the equiatomic NiTi shape memory alloy produced by vacuum arc remelting. In: Materials Science and Engineering A, Vol. 528, pp. 7952-7955, Elsevier.

[8] SADRNEZHAAD, S. K., RAZ, S. B. (2005). Interaction between Refractory Crucible Materials and the Melted NiTi Shape-Memory Alloy, In: Metallurgical and Materials Transactions B, Vol. 36B, pp. 395-403. Springer.

[9] ČAPEK, J., VOJTĚCH, D. (2014). Characterization of Porous Magnesium Prepared by Powder metallurgy - Influence of Powder Shape, In: Manufacturing Technology, Vol. 14, No. 3, pp. 271-275. UJEP. Czech Republic.

[10] NOVÁK, P., MICHALCOVÁ, A. MAREK, I., VODĚROVÁ, M., VOJTĚCH, D. (2012). Possibilities of the observation of chemical reactions during the preparation of intermetallics by reactive sintering. In: Manufacturing Technology, Vol. 12, No. 13, pp. 197-201. UJEP. Czech Republic.

[11] RESNINA, N., BELAYEV, S., VORONKOV A. (2014). Influence of chemical composition and pre-heating temperature on the structure and martensitic transformation in porous TiNi-based shape memory alloys, produced by self-propagating high-temperature synthesis. In: Intermetallics, Vol. 32, pp. 81-89. Elsevier.

[12] KNAISlOVÁ, A., PETERKA, M., NOVÁK, P., VOJTĚCH, D. (2013). Porous Ti-Si Alloys for Implants. In: Manufacturing Technology, Vol. 13, No. 3, pp. 330-333. Elsevier.

[13] http://phys.org/news/2013-02-internal-bones-reveals-behavior.html 